\title{
Ecophysiological aspects of the seed and seedling of Raulinoa echinata (Rutaceae), a species endemic to the riparian forests of Itajaí valley, SC, Brazil
}

\author{
Aspectos ecofisiológicos da semente e da plântula de Raulinoa echinata (Rutaceae), \\ espécie endêmica da vegetação ciliar do vale do Itajaí, SC, Brasil
}

Adriano Antonio Darosci ${ }^{1,2}$ \& Maria Terezinha Silveira Paulilo ${ }^{1}$

\begin{abstract}
In this study aspects of the ecophysiology and morphology of the seed and seedling of Raulinoa echinata was analyzed aiming to contribute with taxonomic studies, ecology and the preservation of this species. Fruit and seeds were collected from a population located in Apiúna (SC). The seedlings obtained from germination were grown in trays filled with substratum composed of dystroferric red nitosoil and sand (1:1) and were irrigated daily. After 15 days of growth, the morphology of the seedlings was observed. The seeds presented ovoid format, axial embryo and fleshy cotyledons, and were exarillate and exalbuminous like are the seeds of other Rutaceae species. Nevertheless, the seeds presented a conspicuous micropyle, an uncommon feature for Rutaceae. The seedlings did not expose the cotyledons, keeping them in the interior of the integument and below the ground, a characteristic of cryptohypogeal germination. Some of these features are important to elucidate the relationship between the species and the riparian forest and the other taxons of the Rutaceae.

Key words: cryptohypogeal germination, endemism, ecophysiology.

\section{Resumo}

Nesse estudo foram analisados aspectos da ecofisiologia e da morfologia da semente e da plântula de Raulinoa echinata, visando a obtenção de dados que possam contribuir para estudos taxonômicos, ecologia e preservação desta espécie. As sementes foram obtidas de frutos coletados de uma população localizada em Apiúna (SC). As plântulas, obtidas da germinação das sementes, foram plantadas em bandejas contendo substrato composto por nitossolo vermelho distroférrico e areia (1:1), irrigadas diariamente e avaliadas após 15 dias de crescimento. A análise das sementes mostrou que estas apresentam formato ovóide, são exariladas, exalbuminosas, apresentando embrião axial e cotilédones carnosos, características morfológicas comuns para a família Rutaceae. Contudo, as sementes apresentaram micrópila conspícua, característica não descrita para a família. A plântula não expõe os cotilédones, mantendo-os no interior do tegumento e abaixo do solo, classificando-a como cripto-hipógeo-reserva. Alguns desses aspectos encontrados são importantes para elucidar a relação da espécie com a vegetação ciliar e com outros gêneros de Rutaceae.
\end{abstract}

Palavras-chave: cripto-hipógeo-reserva, endemismo, ecofisiologia.

\section{Introduction}

Rutaceae, a family of great importance to agronomy and medicine, has approximately 1600 species included in 155 genera (Thorne 1992) and four to six subfamilies, depending on systematic treatment, predominantly distributed in the tropical and subtropical regions of the world (Chase et al. 1999). The monospecific genus Raulinoa, represented by $R$. echinata R.S.Cowan, occurs only in Santa Catarina, Brazil (Cowan \& Smith 1973).

Raulinoa echinata is a species characteristic of and exclusive to the rocky shores and fluvial islands of Itajaí-açu River, located between the cities of Indaial and Ibirama, where many individuals may be partly submerged (Cowan \& Smith 1973) when floods occur (Arioli et al. 2008).

'Universidade Federal de Santa Catarina, Depto. Botânica, C.P. 476, 88040-900, Florianópolis, SC, Brasil.

${ }^{2}$ Corresponding author: solacost@gmail.com 
This is usually a shrubby species, 2 to $3 \mathrm{~m}$ tall, with a thin and sinuous trunk, presenting thorns and oblong-obovate capsule fruits, which have four locules, are $10 \mathrm{~mm}$ in length and $7 \mathrm{~mm}$ in width, and have an obtuse horn, at the dorso-apical side, for each locule (Cowan \& Smith 1973). Some substances, like the limonoids, were isolated from this species and presented a moderate antiparasitic inhibition in relation to the trypomastigote form of Trypanosoma cruzi, and a possible use as drugs with analgesic properties (Biavatti et al. 2002).

Studies on this species are important because of its micro-endemism, and mainly because of the danger of extinction, as it can be found on the list of endangered species of the Brazilian flora issued by the Ministry of Environment (MMA 2008). In its area of occurrence, the species suffers strong anthropic action, due to the presence of a federal highway, the urbanization and the construction of hydroelectric power plants, that may result in a reduction of the water levels in the Itajaí-Açu River.

Studies involving $R$. echinata are rare, and there are no analyses covering the morphology of seeds and seedlings of this species. Considering the high degradation of riparian forests in the past years, and the importance of recovering this vegetation, studies concerning morphology and the early development of plant species can lead to a better understanding of the strategies they develop (Blom \& Voesenek 1996; Rodrigues \& Nave 2000) to adapt to the specific conditions of those areas of occurrence (Costa et al. 2006).

Studies on seedling morphology, together with studies on fruits and seeds, are important as they increase our knowledge of the species, supporting phylogeny and taxonomy (Ferreira \& Cunha 2000; Silva \& Paoli 2000; Souza et al. 2005; Machado et al 2006), since they are easily observable resources and suffer little phenotypic plasticity (Melo et al. 2007). Furthermore, as those studies are crucial to the recognition of the species in the seedling bank (Battilani et al. 2006) and to the characterization of ecological aspects such as dispersal, establishment and the correspondenting stage of ecological succession (Matheus \& Lopes 2007), they contribute to an understanding of the natural recovery and restoration of forests processes (Ferreira \& Cunha 2000; Ressel et al. 2004).

Since this is an endemic species, threatened by extinction and lacking information that could support future studies on its taxonomy, preservation and conservation in situ, this study aimed to characterize some ecophysiological aspects of germination, dispersal and establishment of the seedling, using analyses of the external morphology of the seed and seedling of $R$. echinata.

\section{Materials and Methods}

Fruits of Raulinoa echinata were collected from individuals in the population located in the city of Apiúna (SC), on the banks of the Itajaí-açu River, 2702'08'S ; 49²3'23'W, at various times of the year, since the species produced fruit throughout the year. The climate in that region is humid mesothermal, with hot summers, average temperature of $19.7^{\circ} \mathrm{C}$, and an altitude of 87 m.s.m. (Bertol et al. 2000). A sample of the species was collected, identified and deposited in the Flor Herbarium of the Universidade Federal de Santa Catarina (Florianópolis, SC) under the register Flor 36734. In the laboratory, the fruits were placed in a Petri plate, under laboratory conditions, enabling dehiscence, which happened four days after the collection. The fruits presented one or two seeds for each locule. Immediately after dehiscence, the seeds were stored in a refrigerator, for a period of 15 days, at temperatures of 2 and $4^{\circ} \mathrm{C}$, until they were placed to germinate.

Observation tests on the seeds were made in three situations: in the dark, under light and under light and submerged, using, for each test, 30 randomly selected seeds and equally distributed in Petri plates. For observing of germination in the dark, the seeds were distributed in three Petri plates containing two sheets of filter paper moistened with distilled water and wrapped in two layers of aluminum foil. To observer germination of seeds under light, the seeds were distributed in five Petri plates containing two moistened sheets of filter paper. The same number of Petri plates was used to observe the germination of the seeds under light and submerged; however, only distilled water was used, with the seeds totally submerged. The Petri plates were then kept under the temperature and light conditions found on the lab bench.

In order to obtain seedlings, the seeds were previously sterilized in sodium hypochlorite (20\%), for 30 seconds. A hundred seeds, taken randomly, were placed to germinate in an environment with no light or temperature controls, in Petri plates $(5.5 \mathrm{~cm}$ in diameter $\times 0.5 \mathrm{~cm}$ in height), containing two sheets of filter paper moistened with distilled water. After germination, 50 sprouted seeds were taken randomly and transferred to $40 \mathrm{~cm} \times 20 \mathrm{~cm} \times 5 \mathrm{~cm}$ plastic trays, 
containing sand and dystroferric red nitosoil at a rate of 1:1. The Petri plates and the trays remained under light, moisture and temperature conditions of the laboratory, the trays being watered daily with $100 \mathrm{ml}$ of distilled water.

The seed presenting protrusion of the primary root was considered germinated, and the stage immediately after germination until the emergence of eophylls was considered as seedling (the first laminar structures) (Mourão et al. 2002; Battilani et al. 2006).

To verify the density (mass/volume) of the seeds, four samples, containing different numbers of seeds, had their masses measured in analytical balance. Afterwards, each sample was placed in measuring cylinders with $10 \mathrm{ml}$ of distilled water, in order to measure the volume of water displaced by the sample $\left(\mathrm{g} / \mathrm{cm}^{3}\right)$. The density of the seed was calculated using the equation: density $=$ mass $(\mathrm{g}) /$ volume $\left(\mathrm{cm}^{3}\right)$.

For the morphological analyses, 115 seeds and 10 seedlings were used. The large mortality of seedlings made it impossible to use a greater number of samples for those analyses. For the seeds, the measures taken were: length, width and mass of the seed; length and width of the micropyle; length and width of the hilum; and length, width and mass of the embryo. A scalpel was used to cut the seed integument so that the embryo could be properly observed. The seedlings grew for 15 days under the laboratory conditions previously described, and were then removed from the trays, washed, and the following measurements were taken: length from the root to the apex and length of the hypogeal portion (primary root, root collar, and hypocotyl); length and width of epicotyl, secondary roots and eophylls; and the width of root collar and hypocotyl.

Measurements of the seeds and seedlings were obtained using a caliper to an accuracy of $0.1 \mathrm{~mm}$ and an $0.001 \mathrm{~g}$ analytical balance. Morphological descriptions were made with the aid of a stereomicroscope. The terminology used to describe the morphological structures of $R$. echinata is in accordance with Beltrati (1991), Silva \& Paoli (2000, 2006a, b, c) and Coelho et al. (2001).

\section{Results and Discussion}

The seed of $R$. echinata is exalbuminous, exarillate, oval to oblong, with a convex dorsal side, sharp apical edge and round basal edge, glaborous and with a petrous consistency. The seed coat presents domes or cavities (Fig. 1a-b), does not show brightness and the color varies from dark brown to copper. The seed is $0.473 \mathrm{~cm}( \pm 0.069)$ long and $0.321 \mathrm{~cm}$ wide $( \pm 0,042)$ on average, and its mass is $0.009 \mathrm{~g}( \pm 0.004)$. It has a papyraceous, friable involucre and is involved by a dry, lignified structure of yellowish color (Fig. 1c) that resembles the dry endocarp of Esenbeckia febrifuga described by Beltrati (1991). The micropyle is conspicuous (Fig. 1a-b), is $0.14 \mathrm{~cm}( \pm 0.028)$ long and $0.14 \mathrm{~cm}( \pm 0,036)$ wide, and is located at the hilum base. The hilum is oblong-ovate, and contrasts by showing a lighter coloration in relation to the integument (Fig. 1a-b), and is $0.22 \mathrm{~cm}( \pm 0.049)$ long and $0.11 \mathrm{~cm}( \pm 0.038)$ wide. The embryo is creamyyellow and achlorophyllous (Fig. 1d). It is axial, straight, with narrow embryonic axis and two plano-convex, fleshy cotyledons. It is $0.46 \mathrm{~cm}( \pm 0.021)$ long, 0.27 $\mathrm{cm}( \pm 0,076)$ wide and its mass is $0.006 \mathrm{~g}( \pm 0.001)$. The fruit has 3 to 5 locules (Fig. 1e-f). Literature data do not present this variability; only 4 locules are mentioned for the species (Cowan \& Smith 1973).

Some characteristics presented for $R$. echinata have already been mentioned for the Rutaceae family, such as seeds without endosperm and straight, achlorophyllous embryo (Watson \& Dallwitz 1992). The shapes of the seeds of $R$. echinata have already been found in other Rutaceae species, such as Zanthoxylum rhoifolium Lam. (Silva \& Paoli 2000) and Citrus reticulata L. (Coelho et al. 2001). The dimensions of the seeds of $R$. echinata, compared with other Rutaceae species, present some similarities with Z. rhoifolium $(0.3 \mathrm{~cm}$ $\times 0.3 \mathrm{~cm})($ Silva \& Paoli 2000) and Dictyoloma vandellianum Juss seeds $(0.5 \mathrm{~cm} \times 0.3 \mathrm{~cm})$ (Silva \& Paoli 2006b); yet, they are relatively smaller than the seeds of Balfourodendron riedelianum (Engl.) Engl. $(1.1 \mathrm{~cm} \times 0.26 \mathrm{~cm})($ Silva \& Paoli 2006a), Esenbeckia grandiflora Mart. $(1 \mathrm{~cm} \times 0.5 \mathrm{~cm})$ (Silva \& Paoli 2006c), $P$. pennatifolius $(0.836 \mathrm{~cm} \times 0.488 \mathrm{~cm})$ (Souza et al. $2005)$ and $C$. reticulata $(1.33 \mathrm{~cm} \times 0.52 \mathrm{~cm})($ Coelho et al. 2001). The coloration of $R$. echinata seeds (dark brown to copper) is common among species of the family Rutaceae, which also presents dark coloration (brown or black), such as Z. rhoifolium (Silva \& Paoli 2000), B. riedelianum (Silva \& Paoli 2006a), E. grandiflora (Silva \& Paoli 2006c) and P. pennatifolius (Souza et al. 2005), or copper, such as D. vandellianum (Silva \& Paoli 2006b) (Tab. 1).

Exarillate seeds were also mentioned for $B$. riedelianum (Silva \& Paoli 2006a), D. vandellianum (Silva \& Paoli 2006b), E. grandiflora (Silva \& Paoli 2006c) and Z. rhoifolium (Silva \& Paoli 2000). 

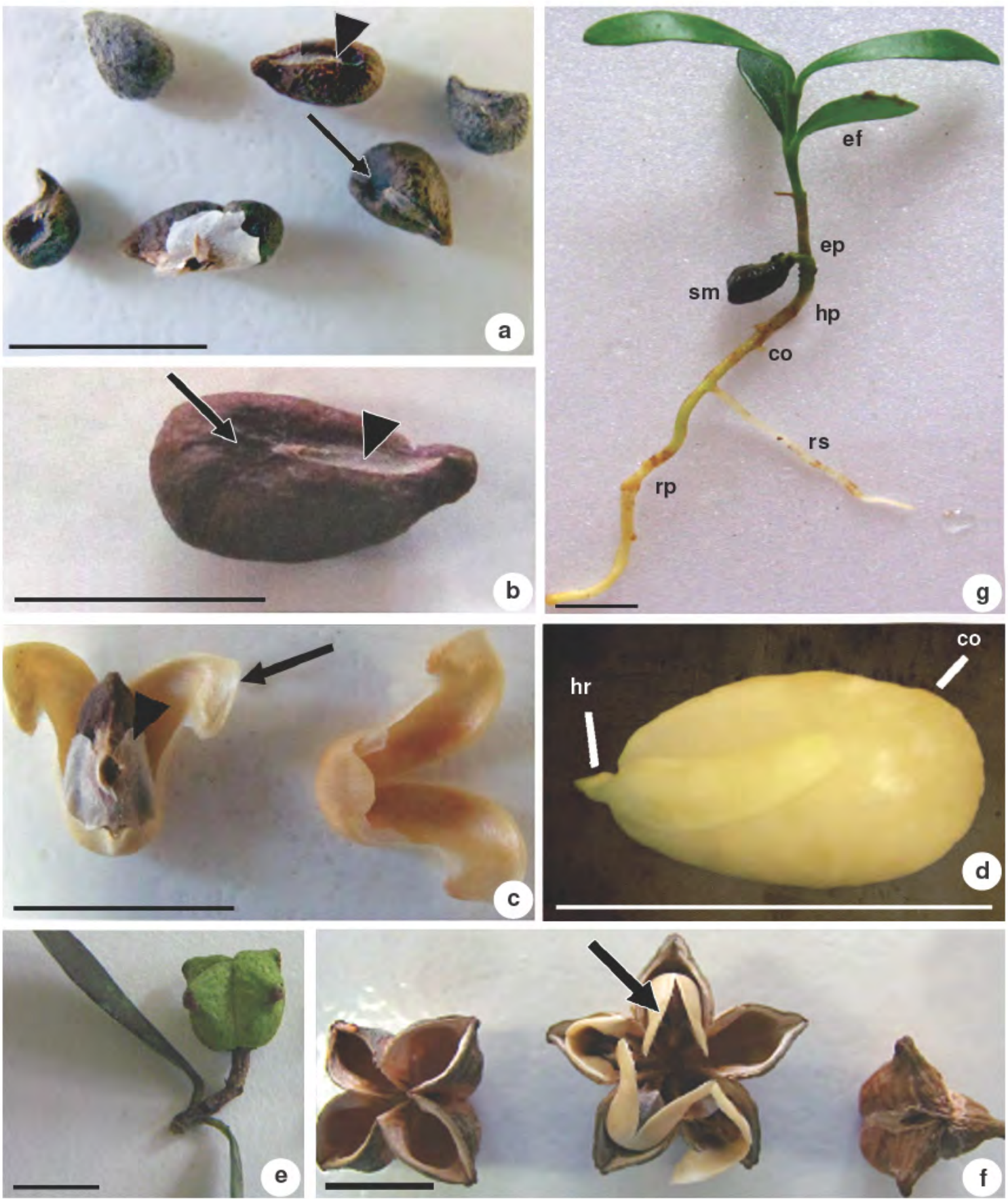

Figure 1 -Fruits and seeds of Raulinoa echinata R.S. Cowan-a. seeds, conspicuous micropyle (arrow) and the hilum in contrast to the integument (head arrow); b. seed, micropyle (arrow) and hilum (head arrow); c. seed involved by the friable wrapper (head arrow) and structure like an endocarp (arrow); d. embryo, cotyledons (co), hipocotyl-radicule axis (hr); e. fruit 4-locular; f. fruits with the 4, 5 and 3-locular, in left to the right, respectively. Look the process of dehiscence and the seeds involved by the structure like an endocarp in the fruit 5-locular (arrow); g. seedling, primary root (rp); secondary root (rs); collar (co); hypocotyls (hp); seed - integument and cotyledons (sm); epicotyls (ep); eophyll (ef). Bar = a, c, e-g $1 \mathrm{~cm}$; b, d $0.5 \mathrm{~cm}$. 
Table 1 - Characteristic of the seeds of Raulinoa echinata R.S. Cowan in comparison with others Rutaceae species cited in literature.

\begin{tabular}{|c|c|c|c|c|c|c|c|c|}
\hline & Exalbuminous & Exarillate & Ovoid & $\begin{array}{l}\text { Dark brown } \\
\text { to copper } \\
\text { colored }\end{array}$ & $\begin{array}{c}\text { Friable } \\
\text { involucre }\end{array}$ & $\begin{array}{l}\text { Hilum with } \\
\text { different } \\
\text { color from the } \\
\text { integument }\end{array}$ & $\begin{array}{c}\text { Conspicuous } \\
\text { micropyle }\end{array}$ & $\begin{array}{c}\text { Fleshy } \\
\text { cotyledons }\end{array}$ \\
\hline $\begin{array}{l}\text { Balfourodendron riedelianum } \\
\text { (Engl.) Engl. (Silva \& } \\
\text { Paoli 2006a) }\end{array}$ & absent & present & absent & present & present & absent & absent & present \\
\hline $\begin{array}{l}\text { Esenbeckia grandiflora Mart. } \\
\text { (Silva \& Paoli 2006c) }\end{array}$ & present & present & absent & present & present & present & absent & present \\
\hline $\begin{array}{l}\text { Dictyoloma vandellianum Juss. } \\
\text { (Silva \& Paoli 2006b) }\end{array}$ & absent & present & absent & present & absent & absent & absent & present \\
\hline $\begin{array}{l}\text { Pilocarpus pennatifolius Lem. } \\
\text { (Souza et al. 2005) }\end{array}$ & absent & absent & absent & present & absent & present & absent & present \\
\hline $\begin{array}{l}\text { Zanthoxylum rhoifolium Lam. } \\
\text { (Silva \& Paoli 2000) }\end{array}$ & absent & present & present & present & absent & present & absent & absent \\
\hline $\begin{array}{l}\text { Citrus reticulata } \mathrm{L} . \\
\text { (Coelho et al. 2001) }\end{array}$ & absent & absent & present & absent & absent & absent & $\begin{array}{c}\text { not } \\
\text { mentioned }\end{array}$ & $\begin{array}{c}\text { not } \\
\text { mentioned }\end{array}$ \\
\hline
\end{tabular}


Exabulminous seeds were also found in E. grandiflora (Silva \& Paoli 2006c) (Tab. 1).

A friable involucre was also observed in $E$. grandiflora (Silva \& Paoli 2006c) and B. riedelianum (Silva \& Paoli 2006a) (Tab. 1). The different coloration of the hilum in relation to the integument is also present in E. grandiflora (Silva \& Paoli 2006c), Z. rhoifolium (Silva \& Paoli 2000) and P. pennatifolius (Souza et al. 2005). Conspicuous micropyle was not described in literature for any Rutaceae species (Tab. 1).

Axial embryo is also present in E. grandiflora (Silva \& Paoli 2006c), Z. rhoifolium (Silva \& Paoli 2000), B. riedelianum (Silva \& Paoli 2006a), D. vandellianum (Silva \& Paoli 2006b) and $C$. reticulata (Coelho et al. 2001) (Tab. 1). Fleshy cotyledons were mentioned for $E$. grandiflora (Silva $\&$ Paoli 2006c), B. riedelianum (Silva \& Paoli 2006a), D. vandellianum (Silva \& Paoli 2006b) and $P$. pennatifolius (Souza et al. 2005) (Tab. 1).

The $R$. echinata seed has an ability to float in the water, since the average value obtained for seed density was $0.457 \mathrm{~g} / \mathrm{cm}^{3}$, which is below the water density value $\left(1 \mathrm{~g} / \mathrm{cm}^{3}\right)$. Kubitzki \& Ziburski (1994), while studying trees from the Amazonian floodplain forests, observed the strong relation between these trees and seed dispersal by hydrochory, since the seeds were able to float, due to the presence of specialized tissues and other attributes, and would fruit precisely during the flood season. The transport of seeds by river water contributes to condense and expand plant biomass in the riparian environments (Ab'Saber 2000). Besides that, a structure resembling a dry endocarp appears to aid seed dispersal. In laboratory, the ejection of seeds attached to these structures was observed, falling approximately $1 \mathrm{~m}$ distant from the fruits in the dehiscence process (Fig. 1f). This ejection may be important for the seeds to reach the rivers, so they can be dispersed. In the Rutaceae, Beltrati (1991) mentions, for the fuit of Esenbeckia febrifuga (St. Hil.) Juss. ex Mart., the presence of a dry and lignified endocarp, which participates in the ejection of the seeds, and Souza et al. (2005) also mentions the liberation of the endocarp together with the seed for Pilocarpus pennatifolius Lem.

According to the analyses of germination characteristics of the R. echinata seed, it was noted that root emission occurred with the breaking of the sharper end (apical) of the seed, and could be observed about 10 days after the sowing, in the three situations tested. From 100 seeds placed to germinate under light and on moistened paper, $76 \%$ germinated. With regard to the seeds placed to germinate submerged, 12 of the 30 seeds $(40 \% 0$ germinated. The seeds were probably indifferent to light for germination, which also occurred in the dark. Of the 30 seeds placed to germinate in the dark, $16(\approx 53 \%)$ germinated. However, more studies are necessary in order to better determine a possible influence of light on the germination of $R$. echinata seeds.

Species that germinate in water may present a strategy similar to the one mentioned by Rodrigues \& Shepherd (2000) for the species that disperse their seeds during the post-flood period, and by Crawford \& Braendle (1996), for annual species: gain time for establishment and development of the young individuals in the area until the next rainy season. Yet, Himatanthus sucuиba (Spruce) Woodson (Apocynaceae) seeds, species from the riparian Amazon forest, germinated less when submerged (Ferreira et al. 2006). According to Blom \& Voesenek (1996), some species may cease to grow when submerged, while others may maintain or even increase biomass production. Furthermore, according to Crawford \& Braendle (1996), many plants present morphological (aerenchyma) and physiological (hormonal and enzymatic controls and alternative metabolic pathways) adaptations, and also life strategies (annual plants, for example) for wetland environments, being tolerant to anoxia or hypoxia. Besides that, according to those authors, smallsized seedlings present a certain advantage in environments that undergo temporary flooding, since the root system is in close proximity to the leaf base, and therefore the distance for oxygen diffusion from the branches to the roots is small.

The germination of the seed independent of the presence or absence of light, on the other hand, is may be due to the fact that the luminosity at the riparian band may vary according to the characteristics of the river channel and the route of the river, and also the physiognomy of the surrounding vegetation (Durigan et al. 2000). Besides that, according to Baskin \& Baskin (2000), many species may germinate both in the presence and in the absence of light, and there are many factors that can lead a species to germinate in the dark or in the light, such as temperature, seasonality and ambient humidity.

The species studied here achieves the seedling stage about 20 days after sowing. In riparian forest environments, the species which are 
able to establish faster may be favored (Rodrigues $\&$ Shepherd 2000). However, of the 50 germinated seeds transferred to plastic trays, only 10 became seedlings. Riparian Forest environments have characteristic environmental traits (Durigan et al. 2000; Rodrigues \& Shepherd 2000). R. echinata seedlings, typical of riparian forests, were developed in a laboratory, without specific luminosity, temperature and humidity control. According to Felfili et al. (1999), factors such as light, water, temperature and edaphic conditions are some of the environmental elements that contribute to the development of the plants, and therefore could influence the results above.

The overall aspect of the $R$. echinata seedling is seen in Figure 1g, where the presence of the pivoting primary root is observed, with a light brown coloration and non-tuberous. The primary root has one to five ramifications. The secondary roots are yellowish-white, about $1.3 \mathrm{~cm}( \pm 0.81)$ long and $0.138 \mathrm{~cm}( \pm 0.019)$ wide. The root collar has the same coloration as the primary root and is thicker. It is $0.112 \mathrm{~cm}( \pm 0.021)$ wide. The hypocotyl, initially, is semi-bent, and then aligns with the root. It is about $0.158 \mathrm{~cm}( \pm 0.031)$ wide and it is cylindrical, short, puffed, green, glaborous and straight next to the root collar. The epicotyl presents scales, is cylindrical and has a green coloration, with average values of $0.591 \mathrm{~cm}( \pm 0,164)$ long a $0.107 \mathrm{~cm}$ $( \pm 0.032)$ wide. The total length of the seedling, from the root to the apex is about $2.96 \mathrm{~cm}$ $( \pm 0.969)$, and the hypogeal portion length (primary root, root collar and hypocotyl) is about $1.27 \mathrm{~cm}( \pm 0.611)$.

Although not shown in detail in Figure 1g, the eophylls is $1.6 \mathrm{~cm}( \pm 0.541)$ long and $0.436 \mathrm{~cm}$ $( \pm 0.14)$ wide. It presents a greenish color, is simple, glaborous, with no apparent glands, slightly coriaceous, oblanceolate-obovate, round apex (retuse), sharp base (cuneate), entire edge, pinnate venation with a simple primary veining leading to not-so-apparent secondary veining, simple petiole, with opposite phyllotaxis. According to the analyses of Arioli et al. (2008), the adult individuals of $R$. echinata presented leaves with simple leaf fronds, with oblanceolate obovate shape, usually retuse apex and cuneate base. Thus, the characteristics of the eophylls are apparently not different from those of the adult leaves.

The $R$. echinata seedling does not show the cotyledons; they are kept inside the integument and under the soil, and so could be classified as reserve cotyledons, and the seedling as cryptohypogean-reserve, based on Garwood's classification (1996).

Crypto-hypogean-reserve seedlings are common in Rutaceae (Watson \& Dallwitz 1992). C. reticulata also keeps the cotyledons under the soil (Coelho et al. 2001). Being a crypto-hypogeanreserve can be advantageous, as it potentially reduces the risk of lethal damage to the aerial part of the seedling (Garwood 1996), since the integument of the seed can work as a protective barrier (Ressel et al. 2004). Crypto-hypogeanreserve seedlings are usually bigger than other seedlings which do not present this characteristic (Ressel et al. 2004). Thus, this characteristic of the seedling is very important for its initial establishment. However, there are species which present the very same model for germination and are different when it comes to the biomass allocation aspect, for they populate different environments, thus developing a larger root or stem according to the light and water requirements for the environment (Ressel et al. 2004).

The species that present the cryptohypogean-reserve characteristic are usually climax species or belong to adverse environments (Ressel et al. 2004; Jacomassi et al. 2007), such as those with little light (Kitajima 1996; Ressel et al. 2004) or periodically flooded (Ressel et al. 2004). This characteristic makes it possible for the seedlings to be initially self-sufficient until environment conditions change, which makes these adverse environments not barriers to be overcome, but niches to be colonized (Ressel et al. 2004).

Many flood-resistant plants are capable of developing a survival mechanism for long floods. Those adaptations are based on rapid changes in the physiological processes, and even in morphological and anatomical features (Blom \& Voesenek 1996). Arioli et al. (2008), analyzing the $R$. echinata leaf, mention the presence of some characteristics that make survival possible in extremely adverse conditions, common to riparian forest environments, such as crystals of calcium phosphate, distributed in idioblasts at the mesophyll, which would act as a reserve for vital physiological processes during floods, and suberin depository on the internal periclinal and anticlinal walls of the epidermal cells, which must play an important role in waterproofing, isolating the more internal tissues during river floods. In perennial species of wetland environments, such as $R$. echinata, the height, 
density, and distance between the tissues and the oxygen source are important factors to supplement this resource to the plant organs subject to hypoxia or anoxia (Crawford \& Braendle 1996). According to Crawford \& Braendle (1996), such adaptations are still sensitive to environmental changes arising from climate, land use and pollution. However, the relation between special morphological features of the rheophytes and the occupation of their respective environments is still not fully understood (Rodrigues \& Tozzi 2007). Thus, further studies on ecophysiological strategies used by rheophytic plants to occupy these environments are required to support the preservation of environments and flora.

\section{Acknowledgments}

We would like to thank the researchers of Instituto de Pesquisas Jardim Botânico do Rio de Janeiro, Marli Pires Morim and José Fernando Andrade Baumgratz, for contributing to the identification of the morphological structures of the species $R$. echinata.

\section{References}

Ab'saber, A.N. 2000. O suporte geoecológico das florestas beiradeiras (ciliares).In: Rodrigues, R.R. \& Leitão-Filho, H.F. (eds.). Matas ciliares: conservação e recuperação. EDUSP; FAPESP, São Paulo. Pp. 15-25.

Arioli, T.; Voltolini, C.H. \& Santos, M. 2008. Morfoanatomia foliar da reófita Raulinoa echinata R.S. Cowan Rutaceae. Acta Botanica Brasilica 22: 723-732.

Baskin, C.C. \& Baskin, J.M. 2000. Seeds - ecology, biogeography, and evolution of dormancy and germination. Academic Prees, San Diego. Pp. 13-16

Battilani, J.L.; Santiago, E.F. \& Souza, A.L.T. 2006. Morfologia de frutos, sementes e desenvolvimento de plântulas e plantas jovens de Maclura tinctoria (L.) D. Don. ex Steud. (Moraceae). Acta Botanica Brasilica 20: 581-589.

Beltrati, C.M. 1991. Estudo morfo-anatômico das sementes e plântulas de Esenbeckia febrifuga (St. Hill.) A. Juss. ex Mart. (Rutaceae). Naturalia 16: 161-169.

Bertol, I; Almeida, J.A.; Almeida, E.X. \& Kurtz, C. 2000. Propriedades físicas do solo relacionadas a diferentes níveis de oferta de forragem de capimelefante-anão CV. MOTT. Pesquisa Agropecuária Brasileira 35: 1047-1054.

Biavatti, M.W.; Albuquerque, S.; Vieira, P.C.; Silva, M.F.G.F.; Fernandes, J.B. 2002. Triterpenoid constituents of Raulinoa echinata. Journal of the Natural Products 65: 562-565.

Blom, C.W.P.M. \& Voesenek, L.A.C.J. 1996. Flooding: the survival strategies of plants. Tree 11: 290-295.
Chase, M.W.; Morton, C.M. \& Kallunki, J.A. 1999. Phylogenetic relationships of Rutaceae: a cladistic analysis of the subfamilies using evidence from RBC and ATP sequence variation. American Journal of Botany 86: 1191-1199.

Coelho, R.I.; Lopes, J.C.; Groth, H.D. \& Souza, N.A. 2001. Caracterização morfológica da planta, frutos, sementes e plântulas de tangerina (Citrus reticulata $\mathrm{L}$.) de ocorrência natural no sul do estado do Espírito Santo. Revista Brasileira de Sementes 23: 294-301.

Costa, A.M.; Gobbi, E.L.; Demuner, V.G. \& Hebling, S.A. 2006. O efeito da inundação do solo sobre o crescimento inicial de Schizolobium parahyba (Vell.) S.F. Blake, guapuruvu. Disponível em $<$ www.naturezaonline.com.br/natureza/conteudo/ pdf/08_Greg\%25C3\%25B3rioTAetal_9198.pdf>. Acesso em 26 jul 2010.

Cowan R.S. \& Smith L.B. 1973. Rutáceas. In: Reitz, R. (ed.). Flora Ilustrada Catarinense. Herbário Barbosa Rodrigues, Itajaí. Pp. 48-51.

Crawford, R.M.M. \& Braendle, R. 1996. Oxygen deprivation stress in a changing environment. Journal of Experimental Botany 47: 145-159.

Durigan, G.; Rodrigues, R.R. \& Shiavini, I. 2000. A heterogeneidade ambiental definindo a metodologia de amostragem da floresta ciliar. In: Rodrigues, R.R. \& Leitão-Filho, H.F. (eds.). Matas ciliares: conservação e recuperação. EDUSP; FAPESP, São Paulo. Pp. 159-168.

Felfili, J.M.; Hilgbert, L.F.; Franco, A.C.; Sousa-Silva, J.C.; Resende, A.V. \& Nogueira, M.V.P. 1999. Comportamento de plântulas de Sclerolobium paniculatum Vog. var. rubiginosum (Tul.) Benth. sob diferentes níveis de sombreamento em viveiro. Revista Brasileira de Botânica 22: 297-301.

Ferreira, C.S.; Piedade, M.T.F. \& Bonates, L.C. 2006. Germinação de sementes e sobrevivência de plântulas de Himatanthus sucuuba (Spruce) Wood. em resposta ao alagamento, nas várzeas da Amazônia Central. Acta Amazônica 36: 413-418.

Ferreira, R.A.\& Cunha, M.C.L. 2000. Aspectos morfológicos de sementes, plântulas e desenvolvimento da muda de craibeira (Tabebuia caraíba (Mart.) Bur.) - Bignoniaceae e pereiro (Aspidosperma pyrifolium Mart.) - Apocynaceae. Revista Brasileira de Sementes 22: 134-143.

Garwood, N.C. 1996. Functional morphology of tropical tree seedlings. In: Swaine, M.D. (ed.). The ecology of tropical forest tree seedlings. UNESCO/ Parthenon Publishing. Paris. Pp. 59-129.

Jacomassi, E; Moscheta, I.S. \& Machado, S.R. 2007. Morfoanatomia e histoquímica de Brosimum gaudichaudii Trécul (Moraceae). Acta Botanica Brasilica 21: 575-597.

Kubitzki, K.\& Ziburski,A. 1994. Seed dispersal in flood plain forests of Amazonia. Biotropica 26: 30-43. 
Kitajima, K. 1996. Cotyledon functional morphology, patterns of seed reserve utilization and regeneration niches of tropical tree seedlings. In: Swaine, M.D. (ed.). The ecology of tropical forest tree seedlings. UNESCO; Parthenon Publishing, Paris. Pp. 193-210.

Machado, C.A.; Oliveira, P.L. \& Mentz, L.A. 2006. SEM observations on seeds of some herbaceous Phyllanthus L. species (Phyllanthaceae). Revista Brasileira de Farmacognosia 16:31-34.

Martins, C.C.; Nakagawa, J. \& Bovi, M.L.A. 1999. Efeito da posição da semente no substrato e no crescimento inicial das plântulas de palmito-vermelho (Euterpe espiritosantensis Fernandes - Palmae). Revista Brasileira de Sementes 21: 164-173.

Matheus, M.T. \& Lopes, J.C. 2007. Morfologia de frutos, sementes e plântulas e germinação de sementes de Erythrina variegata L. Revista Brasileira de Sementes 29: 8-17.

Melo, M.F.F.; Macedo, S.T. \& Daly, D.C. 2007. Morfologia de frutos, sementes e plântulas de nove espécies de Protium Burm. f. (Burseraceae) da Amazônia Central, Brasil. Acta Botanica Brasilica 21: 503-520.

MMA - Ministério do Meio Ambiente. 2008. Instrução normativa de setembro de 2008. Anexo I: Lista oficial das espécies da flora brasileira ameaçadas de extinção. Disponível em <www.mma.gov.br/ estruturas/ascom_boletins/_arquivos/83_ 19092008034949.pdf>. Acesso em 26 jul 2010.

Mourão, K.S.M.; Dias-Pinto, D.; Souza, L.A. \& Moscheta, I.S. 2002. Morfo-anatomia da plântula e do tirodendro de Trichilia catigua A. Juss., T. elegans A. Juss. e T. pallida Sw. (Meliaceae). Acta Scientiarum Maringá 24: 601-610.

Ressel, K; Guilherme, F.A.G.; Schiavini, I. \& Oliveira, P.E. 2004. Ecologia morfofuncional de plântulas de espécies arbóreas da Estação Ecológica do Panga,
Uberlândia, Minas Gerais. Revista Brasileira de Botânica 27: 311-323.

Rodrigues, R.R. \& Nave, A. G. 2000. Heterogeneidade florística das matas ciliares. In: Rodrigues, R.R. \& Leitão-Filho, H.F. (eds.). Matas ciliares: conservação e recuperação. EDUSP; FAPESP, São Paulo. Pp. 45-72.

Rodrigues, R.R. \& Shepherd, G.J. 2000. Fatores condicionantes da vegetação ciliar. In: Rodrigues, R.R. \& Leitão-Filho, H.F. (eds.). Matas ciliares: conservação e recuperação. EDUSP; FAPESP, São Paulo. Pp. 101-108.

Rodrigues, R.S. \& Tozzi, A.M.G.A. 2007. Morfologia de plântulas no clado Vatairea (Leguminosae, Papilionoideae). Rodriguésia 58: 221-229.

Silva, L.L. \& Paoli, A.A.S. 2000. Caracterização morfoanatômica da semente de Zanthoxylum rhoifolium Lam. - Rutaceae. Revista Brasileira de Sementes 22: 250-256.

Silva, L.L. \& Paoli, A.A. S. 2006a. Morfologia e anatomia da semente de Balfourodendron riedelianum (ENGLER) ENGLER - Rutaceae. Revista Brasileira de Sementes 28: 16-20.

Silva, L.L. \& Paoli, A.A.S. 2006b. Morfologia e anatomia da semente de Dictyoloma vandellianum Adr. Juss. (Rutaceae). Revista Brasileira de Sementes 28: 116-120.

Silva, L.L. \& Paoli, A.A.S. 2006c. Morfologia e anatomia da semente de Esenbeckia grandiflora MART. (Rutaceae). Revista Brasileira de Sementes 28: 01-06.

Souza, A.; Mourão, K.S.M. \& Souza, L.A. 2005. Morfologia e anatomia do fruto e da semente em desenvolvimento de Pilocarpus pennatifolius Lem. (Rutaceae). Revista Brasileira de Botânica 28: 745-754.

Thorne, R.F. 1992. An updated phylogenetic classification of the flowering plants. Aliso 13: 365-389.

Watson, L. \& Dallwitz, M.J. 1992. The families of flowering plants: descriptions, illustrations, identification, and information retrieval. Disponível em <http:// www.biologie.uni-hamburg.de/b-online/delta/angio/ www/rutaceae.htm>. Acesso em 8 mar 2009. 